\title{
PENGEMBANGAN MODUL AKIDAH AKHLAK DENGAN PENDEKATAN SAINTIFIK UNTUK SISWA MIN
}

\author{
Nurhasanah \\ Institut Agama Islam Negeri Batusangkar \\ e-mail: nurhasanah2332vm@gmail.com
}

\begin{abstract}
The background of this study is that the learning steps in the module are not yet in accordance with the scientific approach, in the module there are no activities that can motivate students to learn actively and the module components have not been clearly described. The goal to be achieved is to produce a learning module that is valid and practical, so that it can be used by teachers and students in schools, as a guide in the learning process. This type of research is development research, which is a process used to develop and validate educational products. The model used is a 4-D model that is stage (define, design, develop and disseminate). This research only reaches the practicality and stage of develop. The data analysis technique uses the Miles and Huberman model for needs analysis, and uses a formula modified by Riduwan for validity and practicality. The results of the study show that the validity of the Akidah Akhlak module with the scientific approach obtained an average of $89 \%$ with a very valid category, namely its validity. The practical test results from the implementation of the Akidah Akhlak module with the scientific approach obtained an average of $92 \%$ with very practical categories (easy to use and understood by teachers and students). Based on the explanation above, it can be concluded that the Akidah Akhlak module with the scientific approach developed can be declared very valid and very practical so that it is feasible to be used by all Akidah Akhlak subjects in school.
\end{abstract}

Keywords: Modul, Akidah Akhlak, Saintifik

\section{PENDAHULUAN}

Rusli, et., all (1992, p. 2) mengatakan bahwa pengajaran Akidah Akhlak bertujuan agar siswa dapat memahami dan mengamalkan ajaran Islam, membentuk siswa supaya memiliki keyakinan dan kepribadian yang teguh serta membentuk manusia berakhlak mulia sesuai dengan ajaran Islam. Oleh karena itu, di dalam penelitian ini peneliti melakukan pengembangan bahan ajar berupa modul
Akidah Akhlak dengan pendekatan Saintifik di dalam Kurikulum 2013.

Menurut Amri (2013, p. 98-104) "Kurikulum 2013 dapat diimplementasikan oleh guru yang memiliki sikap profesional dalam mengajar, salah satunya dengan cara mengembangan bahan ajar berupa modul, diktat, lembar kerja siswa (LKS), dan handout". Berdasarkan hal tersebut, maka dapat diketahui bahwa ada empat macam bahan ajar yang bisa digunakan guru dalam proses pem- 
belajaran. Di antara sekian banyak bahan ajar di atas, maka peneliti memfokuskan untuk mengembangkan bahan ajar berupa modul di dalam pembelajaran.

Menurut Winkel dalam Susilo, Siswandari \& Bandi, (2016, p. 50-56), modul pembelajaran merupakan "satuan program belajar mengajar yang terkecil, yang dipelajari oleh siswa sendiri secara perseorangan atau diajarkan oleh siswa kepada dirinya sendiri self-instructional."

Berdasarkan pengertian modul di atas, maka dapat diketahui bahwasanya modul merupakan satuan program belajar mengajar yang terkecil, yang dapat dipelajari oleh siswa secara mandiri. Sebagaimana pendapat yang dikemukakan oleh Sani (2014, p. 185-187), pembelajaran dengan sistem modul yaitu adanya umpan balik atau (Feedback), penguasaan tuntas (Mastery), tujuan belajar jelas, menimbulkan motivasi belajar, fleksibilitas belajar, memungkinkan kerja sama, pengajaran remedial. Sedangkan keuntungan bahan ajar berupa modul bagi guru ialah: kepuasan, bantuan individu, pengayaan lebih terbuka, kebebasan dari pertemuan rutin, asas kebermanfaatan, meningkatan profesionalitas guru, tersedia evaluasi formatif yang terencana.
Keunggulan dari modul tersebut juga ditemukan pada penelitian yang dilakukan oleh Suryani, Surya \& Mukhtar (2016, p. 28-35) dengan judul Pengembangan Modul Matematika Berbasis Pendekatan Pembelajaran Saintifik di SMP Negeri 8 Padangsidempuan. Hasil penelitiannya menunjukkan bahwa hasil belajar siswa menggunakan modul secara klasikal adalah 85,71\%. Kepraktisan modul matematika dengan pendekatan saintifik diperoleh rata-rata sebesar 3,31 terkategori praktis.

Menanggapi hasil penelitian di atas, maka peneliti melakukan analisis terhadap modul pembelajaran Akidah Akhlak yang digunakan sekarang pada hari Kamis, tanggal 31 Januari 2019 di kelas V semester II MIN 1 Tanah Datar, di dalam modul tersebut terdapat beberapa kelemahan, di antaranya ialah; a) langkah-langkah pembelajaran di dalam modul belum sesuai dengan pendekatan Saintifik, b) di dalam modul, tidak ada kegiatan yang dapat memotivasi siswa untuk belajar aktif dan c) komponenkomponen modul belum tergambar secara jelas.

Untuk menyikapi permasalahan di atas, maka perlu adanya solusi agar proses pembelajaran berjalan dengan efektif dan efisien serta tercapainya tujuan pembelajaran. Salah satu 
solusinya yaitu dengan mengembangkan bahan ajar berupa modul dengan pendekatan saintifik, dengan alasan pendekatan saintifik menjadikan siswa lebih aktif dan dapat mendorong siswa untuk menemukan permasalahan serta menyelesaikannya sendiri. Pembelajaran dalam pendekatan saintifik, membiasakan siswa untuk menemukan kebenaran ilmiah, bukan berhayal. Penerapan pendekatan saintifik dalam pem-belajaran menuntut adanya per-ubahan bentuk pembelajaran indi-vidu yang berbeda dengan pem-belajaran konvensional. Selain itu, melalui pendekatan saintifik ini yang sebelumnya siswa diberi tahu, maka berubah menjadi siswa aktif mencari tahu (Abduh, 2018, p. 307-318).

Sebagaimana penelitian yang dilakukan oleh Erny, Haji \& Widada (2017, p. 1-22), dengan judul penelitian: Pengaruh Pendekatan Saintifik pada Pembelajaran Matematika Terhadap Kemampuan Pemecahan Masalah dan Kemampuan Berpikir Tingkat Tinggi Siswa Kelas X IPA SMA Negeri 1 Kepahiang. Hasil penelitiannya yaitu terdapat pengaruh positif pendekatan saintifik pada pembelajaran Matematika terhadap kemampuan pemecahan masalah dengan meningkatnya rata-rata nilai posttes jika dibandingkan dengan rata-rata nilai pretes sebesar 97,5\% untuk kelas eksperimen, sedangkan
96,9\% untuk kelas kontrol dengan pendekatan kontekstual. Hasil penelitian juga menunjukkan terdapat pengaruh positif pendekatan saintifik pada pembelajaran Matematika terhadap kemampuan berpikir tingkat tinggi (Higt Order Thingking Skill) dengan adanya peningkatan rata rata nilai posttes yang dibandingkan dengan rata -rata nilai pretes sebesar 97,4\% untuk kelas eksperimen dan 96,7\% untuk kelas kontrol dengan pendekatan kontekstual.

\section{METODE PENELITIAN}

Jenis penelitian yang digunakan adalah penelitian pengembangan. Penelitian pengembangan adalah suatu proses yang digunakan untuk mengembangkan dan menvalidasi produk pembelajaran. Penelitian ini dilakukan di MIN 1 Tanah Datar, mengenai pengembagan modul Akidah Akhlak dengan pendekatan Saintifik. Adapun Model pengembangan yang peneliti gunakan dalam pengembangan modul Akidah Akhlak dengan pendekatan saintifik ini yaitu menggunakan model pengembangan perangkat pembelajaran Thiagarajan, Semmel dan Semmel, yaitu model 4-D (define, design, develop, disseminate) pendefinisian, perancangan, pengembangan dan penyebaran (Suryani, Surya, Mukhtar, 2016, p. 2835). Prosedur pengembangan pene- 
litian yang digunakan dalam dan kepada satu orang guru Akidah penelitian ini adalah model 4-D. Akhlak.

Thiagarajan mengemukakan dalam Sugiyono, (2017, p. 37) bahwa model 4-D terdiri dari 4 tahap pengembangan yaitu define, design, develop dan dessiminate.

Dalam menentukan subjek uji coba, masing-masing tahapan penelitian mengacu pada prosedur penelitian pengembangan, sehingga ditetapkan sesuai dengan kebutuhan masing-masing tahapan penelitian. 1) Subjek Uji Coba Analisis Kebutuhan yaitu siswa kelas V semester II MIN 1 Tanah Datar dan guru mata pelajaran Akidah Akhlak. 2) Subjek Uji Coba Tahap Validitas ialah 3 orang validator yaitu pakar Pendidikan Agama Islam, pakar IT dan pakar Pendidikan. Kemudian dosen pembimbing I dan II. 3) Subjek Uji Coba Tahap Praktikalitas yaitu siswa kelas V semester II MIN 1 Tanah Datar yang bejumlah 32 orang siswa

\section{HASIL PENELITIAN}

\section{Tahap Validasi}

Prototipe modul yang telah dirancang dan didiskusikan dengan pembimbing selanjutnya divalidasikan oleh pakar Pendidikan Agama Islam, Pakar IT, dan Pakar Pendidikan yang terdiri atas 3 orang pakar. Setelah divalidasikan, peneliti berdiskusi langsung dengan validator tentang kevalidan produk yang dirancang serta meminta saran-saran untuk perbaikan produk. Berikut diuraikan hasil validasi produk yang telah dikembangkan.

1) Hasil Analisis Validasi Modul

\section{Akidah Akhlak dengan \\ Pendekatan Saintifik}

Data hasil pengolahan validasi modul Akidah Akhlak dengan pendekatan Saintifik dari validator dituliskan pada tabel 1 berikut:

Tabel 1 Hasil Analisis Validasi Modul Akidah Akhlak dengan pendekatan Saintifik

\begin{tabular}{|r|l|c|c|r|c|c|l|l|}
\hline No & $\begin{array}{l}\text { Aspek Yang } \\
\text { divalidasi }\end{array}$ & \multicolumn{3}{|c|}{ Validator } & Jml & \multicolumn{1}{|l|}{$\begin{array}{l}\text { Skor } \\
\text { Maks }\end{array}$} & \% & Ket \\
\cline { 3 - 6 } & Kelayakan isi & 28 & 29 & 24 & 81 & 90 & $90 \%$ & Sangat Valid \\
\hline 2 & $\begin{array}{l}\text { Kelayakan } \\
\text { bahasa }\end{array}$ & 18 & 17 & 16 & 51 & 60 & $85 \%$ & Sangat Valid \\
\hline 3 & $\begin{array}{l}\text { Kelayakan } \\
\text { penyajian }\end{array}$ & 30 & 28 & 24 & 82 & 90 & $91 \%$ & Sangat Valid \\
\hline
\end{tabular}




\begin{tabular}{|c|l|c|c|c|c|c|c|c|}
4 & $\begin{array}{l}\text { Kelayakan } \\
\text { kegrafikan }\end{array}$ & 17 & 19 & 17 & 53 & 60 & $88 \%$ & Sangat Valid \\
\hline 5 & $\begin{array}{l}\text { Pendekatan } \\
\text { Saintifik }\end{array}$ & 52 & 51 & 46 & 153 & 165 & $92 \%$ & Sangat Valid \\
\hline Jumlah & $\mathbf{1 4 5}$ & $\mathbf{1 4 4}$ & $\mathbf{1 2 7}$ & $\mathbf{4 1 6}$ & $\mathbf{4 6 5}$ & $\mathbf{8 9} \%$ & $\begin{array}{c}\text { Sangat } \\
\text { Valid }\end{array}$ \\
\hline
\end{tabular}

Dari hasil validasi modul yang dinilai oleh 3 orang validator, seperti pada tabel 4.1 di atas, dapat diketahui rata-rata hasil validasi secara umum adalah 88\% dengan kategori sangat valid. Dari aspek-aspek yang dinilai didapat rata-rata nilai pada kelayakan isi $90 \%$, kelayakan bahasa $85 \%$, kelayakan penyajian $86 \%$, kelayakan kegrafikan $88 \%$, pendekatan Saintifik 92\%. Dapat disimpulkan modul Akidah Akhlak dengan Pendektaan Saintifik yang dikembangkan sudah valid dan dapat digunakan dalam proses pembelajaran. Pengkategorian hasil validitas modul Akidah Akhlak dengan pendekatan Saintifik berdasarkan pendapat Riduwan (2005, p. $89)$, dimana persentase antara $0 \%$ -
$20 \%$ dengan kategori tidak valid, 21\% - 40\% dengan kategori kurang valid, $41 \%$ - $60 \%$ dengan kategori cukup valid, $61 \%$ - 80\% dengan kategori valid, $81 \%$ - 100\% dengan kategori sangat valid. Berdasaran hasil validasi dari modul Akidah Akhlak dengan pendekatan Saintifik yang telah dinilai validator menunjukkan modul yang dikembangkan sangat valid. Hal ini berarti modul yang dikembangkan sudah baik dan dapat digunakan.

2) Hasil Analisis Validasi Lembar RPP Akidah Akhlak dengan Pendekatan Saintifik

Data hasil pengolahan validasi RPP Akidah Akhlak dengan pendekatan Saintifik dari validator dituliskan pada table 2 berikut:

Tabel 2 Hasil Analisis Validasi RPP Akidah Akhlak dengan Pendekatan Saintifik

\begin{tabular}{|r|l|c|r|r|c|c|c|c|}
\hline No & $\begin{array}{l}\text { Aspek Yang } \\
\text { divalidasi }\end{array}$ & \multicolumn{3}{|c|}{ Validator } & Jml & $\begin{array}{l}\text { Skor } \\
\text { Maks }\end{array}$ & \% & Ket \\
\cline { 2 - 9 } & Format RPP & 5 & 5 & 4 & 14 & 15 & $93 \%$ & $\begin{array}{c}\text { Sangat } \\
\text { Valid }\end{array}$ \\
\hline 2 & Isi RPP & 23 & 23 & 20 & 66 & 75 & $88 \%$ & $\begin{array}{c}\text { Sangat } \\
\text { Valid }\end{array}$ \\
\hline 3 & $\begin{array}{l}\text { Penggunaan } \\
\text { Bahasa }\end{array}$ & 12 & 14 & 12 & 38 & 45 & $84 \%$ & $\begin{array}{c}\text { Sangat } \\
\text { Valid }\end{array}$ \\
\hline
\end{tabular}

Pengembangan Modul Akidah Akhlak dengan Pendekatan Saintifik... | 193 


\begin{tabular}{|c|c|c|c|c|c|c|c|}
\hline Jumlah & 40 & 42 & 36 & 118 & 135 & $88 \%$ & $\begin{array}{c}\text { Sangat } \\
\text { Valid }\end{array}$ \\
\hline
\end{tabular}

Dari hasil validasi RPP yang dinilai oleh 3 orang validator, seperti pada tabel 4.3 di atas, dapat diketahui rata-rata hasil validasi secara umum adalah 88\% dengan kategori sangat valid. Dari aspek-aspek yang dinilai didapat rata-rata nilai format RPP $93 \%$, isi RPP $88 \%$, penggunaan bahasa $84 \%$. Dapat disimpulkan RPP Akidah Akhlak dengan Pendektaan Saintifik yang dirancang sudah valid dan dapat digunakan dalam proses pembelajaran. Pengkategorian hasil validitas RPP Akidah Akhlak dengan pendekatan saintifik berdasarkan pendapat Riduwan (2005, p. 89), $40 \%$ dengan kategori kurang valid, $41 \%$ - $60 \%$ dengan kategori cukup valid, $61 \%$ - $80 \%$ dengan kategori valid, $81 \%$ - 100\% dengan kategori sangat valid.

\section{3) Hasil Analisis Validasi Lembar Instrumen Angket Respon Siswa}

Untuk mengetahui praktikalitas terhadap modul Akidah Akhlak dengan pendekatan Saintifik, maka peneliti memberikan angket kepada siswa. Sebelum angket diberikan kepada siswa terlebih dahulu angket divalidasikan kepada validator. Angket ini divalidasikan oleh 3 orang validator. Secara garis besar hasil dimana persentase antara $0 \%-20 \%$ validasi angket dapat dilihat pada dengan kategori tidak valid, $21 \%$ - tabel 3 berikut:

Tabel 3 Hasil Analisis Validasi Lembar Instrumen Angket Respon Siswa tentang Praktikalitas Modul Akidah Akhlak dengan Pendekatan Saintifik

\begin{tabular}{|c|c|c|c|c|c|c|c|c|}
\hline \multirow[t]{2}{*}{ No } & \multirow{2}{*}{$\begin{array}{c}\text { Aspek yang } \\
\text { Divalidasi }\end{array}$} & \multicolumn{3}{|c|}{ Validator } & \multirow[t]{2}{*}{ Jml } & \multirow{2}{*}{$\begin{array}{l}\text { Skor } \\
\text { Maks }\end{array}$} & \multirow[t]{2}{*}{$\%$} & \multirow[t]{2}{*}{ Ket } \\
\hline & & 1 & 2 & 3 & & & & \\
\hline 1 & Format Angket & 5 & 5 & 4 & 14 & 15 & $93 \%$ & $\begin{array}{c}\text { Sangat } \\
\text { Valid }\end{array}$ \\
\hline 2 & Petunjuk & 5 & 5 & 4 & 14 & 15 & $93 \%$ & $\begin{array}{c}\text { Sangat } \\
\text { Valid }\end{array}$ \\
\hline 3 & $\begin{array}{c}\text { Penggunaan } \\
\text { Bahasa }\end{array}$ & 12 & 13 & 12 & 37 & 45 & $82 \%$ & $\begin{array}{c}\text { Sangat } \\
\text { Valid }\end{array}$ \\
\hline & Rata-rata & 22 & 23 & 20 & 65 & 75 & $86 \%$ & $\begin{array}{c}\text { Sangat } \\
\text { Valid }\end{array}$ \\
\hline
\end{tabular}

Dari analisis hasil validasi atas, dapat diketahui rata-rata hasil angket yang dinilai oleh 3 orang validasi secara umum adalah 86\% validator, seperti pada tabel 4.5 di dengan kategori sangat valid. Dari 
aspek-aspek yang dinilai didapat ratarata nilai pada format angket 93\%, petunjuk $93 \%$, bahasa yang digunakan $82 \%$. Pengkategorian hasil validitas angket respon siswa berdasarkan pendapat Riduwan (2005, p. 89), dimana persentase antara $0 \%-20 \%$ dengan kategori tidak valid, $21 \%$ $40 \%$ dengan kategori kurang valid, $41 \%$ - $60 \%$ dengan kategori cukup valid, $61 \%-80 \%$ dengan kategori valid, $81 \%$ - 100\% dengan kategori sangat valid.

\section{4) Hasil Analisis Validasi Lembar Instrumen Angket Guru}

Untuk mengetahui praktikalitas terhadap modul Akidah Akhlak dengan Pendekatan Saintifik, maka peneliti memberikan angket kepada guru Akidah Akhlak. Sebelum dilakukan pratikalitas oleh guru, terlebih dahulu lembar pratikalitas divalidasikan kepada 3 orang validator. Secara garis besar hasil validasi lembar pratikalitas modul dapat dilihat pada tabel 4 berikut:

Tabel 4 Hasil Analisis Validasi Lembar Instrumen Angket Guru tentang Praktikalitas Modul Akidah Akhlak dengan Pendekatan Saintifik

\begin{tabular}{|c|c|c|c|c|c|c|c|c|}
\hline No & \multirow{2}{*}{$\begin{array}{c}\text { Aspek yang } \\
\text { Divalidkan }\end{array}$} & \multicolumn{3}{|c|}{ Validator } & Jml & $\begin{array}{c}\text { Skor } \\
\text { Maks }\end{array}$ & $\mathbf{0}$ & Ket \\
\cline { 3 - 8 } & & $\mathbf{1}$ & $\mathbf{2}$ & $\mathbf{3}$ & & & & \\
\hline 1 & Format Angket & 5 & 5 & 4 & 14 & 15 & $93 \%$ & $\begin{array}{c}\text { Sangat } \\
\text { Valid }\end{array}$ \\
\hline 2 & Petunjuk & 5 & 5 & 4 & 14 & 15 & $93 \%$ & $\begin{array}{c}\text { Sangat } \\
\text { Valid }\end{array}$ \\
\hline 3 & $\begin{array}{c}\text { Penggunaan } \\
\text { Bahasa }\end{array}$ & 13 & 14 & 12 & 39 & 45 & $86 \%$ & $\begin{array}{c}\text { Sangat } \\
\text { Valid }\end{array}$ \\
\hline \multicolumn{2}{|c|}{ Rata-rata } & $\mathbf{2 3}$ & $\mathbf{2 4}$ & $\mathbf{2 0}$ & $\mathbf{6 7}$ & $\mathbf{7 5}$ & $\mathbf{8 9} \%$ & $\begin{array}{c}\text { Sangat } \\
\text { Valid }\end{array}$ \\
\hline
\end{tabular}

Dari analisis hasil validasi angket guru yang dinilai oleh 3 orang validator, seperti pada tabel di atas, dapat diketahui rata-rata hasil validasi secara umum adalah $89 \%$ dengan kategori sangat valid. Dari aspekaspek yang dinilai di dapat rata-rata nilai pada format angket 93\%, petunjuk $93 \%$, penggunaan bahasa $86 \%$. Pengkategorian hasil validitas lembar angket guru berdasarkan pendapat Riduwan (2005, p. 89), dimana persentase antara $0 \%-20 \%$ dengan kategori tidak valid, 21\% $40 \%$ dengan kategori kurang valid, $41 \%$ - $60 \%$ dengan kategori cukup valid, $61 \%$ - 80\% dengan kategori valid, $81 \%$ - 100\% dengan kategori sangat valid. 
5) Lembar Instrumen Observasi Modul Akidah Akhlak dengan Pembelajaran Menggunakan pendekatan Saintifik. Sebelum Modul Akidah Akhlak dengan melakukan observasi terlebih dahulu Pendekatan Saintifik

Selain memberikan angket kepada guru, peneliti juga melakukan observasi pembelajaran menggunakan lembar observasi divalidasikan kepada validator. Secara garis besar hasil validasi lembar observasi dapat dilihat pada tabel 5 berikut:

Tabel 5 Hasil Analisis Validasi Lembar Instrumen Observasi pembelajaran menggunakan Modul Akidah Akhlak dengan pendekatan Saintifik

\begin{tabular}{|c|c|c|c|c|c|c|c|c|}
\hline No & \multirow{2}{*}{$\begin{array}{c}\text { Aspek yang } \\
\text { Divalidkan }\end{array}$} & \multicolumn{3}{|c|}{ Validator } & Jml & $\begin{array}{c}\text { Skor } \\
\text { Maks }\end{array}$ & $\mathbf{2}$ & Ket \\
\cline { 3 - 7 } & & $\mathbf{1}$ & $\mathbf{2}$ & $\mathbf{3}$ & & & & \\
\hline 1 & $\begin{array}{c}\text { Format } \\
\text { Observasi }\end{array}$ & 4 & 4 & 4 & 12 & 15 & $80 \%$ & Valid \\
\hline 2 & Petunjuk & 5 & 5 & 4 & 14 & 15 & $93 \%$ & $\begin{array}{c}\text { Sangat } \\
\text { Valid }\end{array}$ \\
\hline 3 & $\begin{array}{c}\text { Penggunaan } \\
\text { Bahasa }\end{array}$ & 13 & 13 & 12 & 38 & 45 & $84 \%$ & $\begin{array}{c}\text { Sangat } \\
\text { Valid }\end{array}$ \\
\hline 4 & $\begin{array}{c}\text { Aspek-aspek } \\
\text { yang Diamati }\end{array}$ & 9 & 9 & 9 & 27 & 30 & $90 \%$ & $\begin{array}{c}\text { Sangat } \\
\text { Valid }\end{array}$ \\
\hline & Rata-rata & $\mathbf{3 1}$ & $\mathbf{3 1}$ & $\mathbf{2 9}$ & $\mathbf{9 1}$ & $\mathbf{1 0 5}$ & $\mathbf{8 6} \%$ & $\begin{array}{c}\text { Sangat } \\
\text { Valid }\end{array}$ \\
\hline
\end{tabular}

Dari analisis hasil validasi lembar observasi yang dinilai oleh 3 orang validator seperti pada tabel di atas, dapat diketahui rata-rata hasil validasi secara umum adalah $86 \%$ dengan kategori sangat valid. Dari aspek-aspek yang dinilai didapat ratarata nilai pada format lembar observasi $80 \%$, petunjuk 93\%, penggunaan bahasa $84 \%$, aspek-aspek yang diamati 90\%. Pengkategorian hasil validitas lembar observasi berdasarkan pendapat Riduwan (2005, p. 89), dimana persentase antara $0 \%-20 \%$ dengan kategori tidak valid, 21\% $40 \%$ dengan kategori kurang valid, $41 \%$ - 60\% dengan kategori cukup valid, $61 \%-80 \%$ dengan kategori valid, $81 \%$ - 100\% dengan kategori sangat valid.

Setelah proses validasi dengan pakar selesai, selanjutnya dilakukan revisi sesuai dengan saran-saran validator. Setelah dilakukan revisi dilakukan kembali diskusi dengan validator sampai akhirnya semua perangkat dapat digunakan untuk penelitian. 


\section{a. Tahap Praktikalitas}

Untuk melihat praktikalitas modul Akidah Akhlak dengan pendekatan saintifik untuk siswa MI, maka modul ini dilakukan uji coba dikelas V MIN 1 Tanah Datar pada tanggal 08 Mei 2019. Data tentang praktikalitas modul Akidah Akhlak dengan Pendekatan Saintifik diperoleh dari angket respon siswa, angket guru serta observasi pelaksanaan kegiatan pembelajaran menggunakan modul Akidah Akhlak dengan Pendekatan Saintifik dikelas V MIN 1 Tanah Datar. Berikut diuraikan hasil yang diperoleh mengenai praktikalitas modul Akidah Akhlak dengan Pendekatan Saintifik.

\section{1) Hasil Analisis Lembar Instrumen Angket Respon Siswa}

Peneliti menyebarkan angket kepada siswa kelas V MIN 1 Tanah Datar pada tanggal 08 Mei 2019 untuk mengetahui lebih lanjut tentang kepraktisan penggunaan modul Akidah Akhlak dengan Pendekatan Saintifik pada materi menghindari akhlak tercela (kikir dan serakah). Berdasarkan hasil dari angket respon siswa tentang praktikalitas modul Akidah Akhlak yang peneliti peroleh, maka didapatkan data sebagai berikut:

Table 6 Hasil Analisis Lembar Instrumen Angket Respon Siswa tentang Kepraktisan Modul Akidah Akhlak dengan Pendekatan Saintifik

\begin{tabular}{|c|c|c|c|c|c|}
\hline No & Aspek Penilaian & $\begin{array}{c}\text { Skor } \\
\text { Siswa }\end{array}$ & $\begin{array}{l}\text { Skor } \\
\text { maks }\end{array}$ & $\%$ & Kriteria \\
\hline 1. & Pembelajaran mandiri & 484 & 512 & $94 \%$ & Sangat Praktis \\
\hline 2. & Bahan ajar & 1074 & 1152 & $93 \%$ & Sangat Praktis \\
\hline 3. & $\begin{array}{l}\text { Sistematis, } \\
\text { operasional dan } \\
\text { terarah }\end{array}$ & 477 & 512 & $93 \%$ & Sangat Praktis \\
\hline 4. & Pedoman penggunaan & 238 & 256 & $92 \%$ & Sangat Praktis \\
\hline 5. & Proses pembelajaran & 356 & 384 & $92 \%$ & Sangat Praktis \\
\hline 6. & $\begin{array}{l}\text { Memberikan } \\
\text { pemahaman kepada } \\
\text { siswa }\end{array}$ & 242 & 256 & $94 \%$ & Sangat Praktis \\
\hline 7. & Pendekatan ilmiah & 485 & 512 & $94 \%$ & Sangat Praktis \\
\hline 8. & Informasi & 240 & 256 & $93 \%$ & Sangat Praktis \\
\hline \multicolumn{2}{|r|}{ Rata-Rata } & 3596 & 3840 & $93 \%$ & Sangat Praktis \\
\hline
\end{tabular}


Berdasarkan hasil analisis dari angket respon siswa di atas, maka dapat diketahui bahwa modul Akidah Akhlak dengan pendekatan Saintifik di nilai sangat praktis dengan ratarata 93\%. Pengkategorian hasil praktikalitas Modul akidah Akhlak berdasarkan pendapat Riduwan (2005, p. 89), dimana persentase antara $0 \%$ $20 \%$ dengan kategori tidak praktis, $21 \%$ - $40 \%$ dengan kategori kurang praktis, $41 \%-60 \%$ dengan kategori cukup praktis, $61 \%$ - $80 \%$ dengan kategori praktis, $81 \%$ - 100\% dengan kategori sangat praktis.

\section{2) Hasil Analisis Lembar Instrumen Angket Guru}

Setelah selesai pembelajaran menggunakan modul Akidah Akhlak dengan pendekatan Saintifik peneliti juga memberikan angket kepada guru mata pelajaran Akidah Akhlak untuk mengetahui kepraktisan dari modul tersebut. Berikut hasil dari angket guru:

Tabel 7 Hasil Analisis Lembar Instrumen Angket Guru tentang Kepraktisan Modul Akidah Akhlak dengan Pendetakan Saintifik

\begin{tabular}{|c|l|c|c|c|c|}
\hline No & $\begin{array}{c}\text { Aspek yang } \\
\text { Divalidasi }\end{array}$ & $\begin{array}{c}\text { Skor } \\
\text { Penilai }\end{array}$ & $\begin{array}{c}\text { Skor } \\
\text { Maks }\end{array}$ & $\mathbf{\%}$ & Ket \\
\hline 1 & Kelayakan isi & 29 & 30 & $96 \%$ & Sangat Praktis \\
\hline 2 & Kelayakan bahasa & 20 & 20 & $100 \%$ & Sangat Praktis \\
\hline 3 & $\begin{array}{l}\text { Kelayakan } \\
\text { penyajian }\end{array}$ & 28 & 30 & $93 \%$ & Sangat Praktis \\
\hline 4 & $\begin{array}{l}\text { Kelayakan } \\
\text { kegrafikan }\end{array}$ & 20 & 20 & $100 \%$ & Sangat Praktis \\
\hline 5 & $\begin{array}{l}\text { Pendekatan } \\
\text { Saintifik }\end{array}$ & 53 & 55 & $96 \%$ & Sangat Praktis \\
\hline & Rata-rata & $\mathbf{1 5 0}$ & $\mathbf{1 5 5}$ & $\mathbf{9 7 \%}$ & Sangat Praktis \\
\hline
\end{tabular}

Berdasarkan tabel di atas, maka akhlak tercela (kikir dan serakah). dapat diketahui hasil dari angket guru Pengkategorian kepraktisan modul adalah sangat praktis dengan rata-rata berdasarkan pendapat Riduwan (2005, $97 \%$. Hal ini berarti modulnya sangat p. 89), dimana persentase antara $0 \%$ praktis dan sangat membantu peserta $20 \%$ dengan kategori tidak praktis, didik dalam belajar, terutama bagi 21\% - 40\% dengan kategori kurang guru dengan pendekatan Saintifik, praktis, 41\% - 60\% dengan kategori khususnya pada materi menghindari cukup praktis, 61\% - 80\% dengan 
kategori praktis, $81 \%-100 \%$ dengan kategori sangat praktis.

\section{3) Hasil Analisis Lembar Instrumen Observasi}

Peneliti juga melakukan observasi mengenai kepraktisan penggunaan modul Akidah Akhlak dengan pendekatan Saintifik. Dalam melakukan observasi peneliti meminta satu orang observer untuk membantu peneliti dalam melakukan penilaian terhadap keterlaksanaan kegiatan pembelajaran dengan menggunakan modul tersebut. Berikut ini hasil dari pengamatan observer.

Tabel 8 Hasil Analisis Lembar Instrumen Observasi Pelaksanaan Pembelajaran Menggunakan Modul Akidah Akhlak dengan pendekatan Saintifik

\begin{tabular}{|c|l|c|c|c|c|}
\hline No & $\begin{array}{c}\text { Aspek yang } \\
\text { Divalidasi }\end{array}$ & $\begin{array}{c}\text { Skor } \\
\text { Observer }\end{array}$ & $\begin{array}{c}\text { Skor } \\
\text { Maks }\end{array}$ & $\%$ & Kriteria \\
\hline 1 & $\begin{array}{l}\text { Kegiatan } \\
\text { Pendahuluan }\end{array}$ & 53 & 60 & $88 \%$ & Sangat Praktis \\
\hline 2 & Kegiatan Inti (5 M) & 76 & 90 & $84 \%$ & Sangat Praktis \\
\hline 3 & Kegiatan Penutup & 35 & 40 & $87 \%$ & Sangat Praktis \\
\hline & Rata-Rata & $\mathbf{1 6 4}$ & $\mathbf{1 9 0}$ & $\mathbf{8 6} \%$ & Sangat Praktis \\
\hline
\end{tabular}

Berdasarkan tabel di atas, diketahui hasil observasi pembelajaran menggunakan modul Akidah Akhlak dengan Pendekatan Saintifik di kelas V MIN 1 Tanah Datar adalah sangat praktis dengan rata-rata $86 \%$. Pengkategorian hasil praktikalitas modul berdasarkan pendapat Riduwan (2005, p. 89), di mana persentase antara $0 \%-20 \%$ dengan kategori tidak praktis, $21 \%-40 \%$ dengan kategori kurang praktis, 41\% $60 \%$ dengan kategori cukup praktis, $61 \%$ - 80\% dengan kategori praktis, praktis.

\section{PEMBAHASAN}

\section{Validitas Produk}

Rata-rata penilaian modul Akidah Akhlak dengan pendekatan Saintifik materi menghindari akhlak tercela (kikir dan serakah) adalah 88\% dengan kategori sangat valid. Berdasarkan penilaian validator semua persyaratan modul sudah terpenuhi dan dapat diukur, sesuai dengan pengkategorian hasil validitas 
berdasarkan pendapat Riduwan (2005, ilustrasi, gambar, foto, desain p. 89), dimana persentase antara $0 \%$ - tampilan.

$20 \%$ dengan kategori tidak valid, $21 \%$ - 40\% dengan kategori kurang valid, $41 \%$ - $60 \%$ dengan kategori cukup valid, $61 \%$ - $80 \%$ dengan kategori valid, $81 \%$ - $100 \%$ dengan kategori sangat valid.

Menurut Lidy dkk dalam Susilo, Siswandari \& Bandi, (2016, p. 51), kualitas modul dapat dilihat dari beberapa aspek di antaranya: 1) aspek kelayakan isi, yang mencakup: kesesuaian dengan SK dan KD, kesesuaian dengan perkembangan anak, kesesuaian dengan kebutuhan bahan ajar, kebenaran substansi materi pembelajaran, manfaat untuk penambahan wawasan, kesesuaian dengan nilai moral dan nilai-nilai sosial, 2) aspek kelayakan bahasa, yang mencakup: keterbacaan, kejelasan informasi, kesesuaian dengan kaidah Bahasa Indonesia yang baik dan benar, Pemanfaatan bahasa secara efektif dan efisien (jelas dan singkat), 3) aspek kelayakan penyajian, yang mencakup: kejelasan tujuan (indikator) yang ingin dicapai, urutan sajian, pemberian motivasi, daya tarik, interaksi (pemberian stimulus dan respon), kelengkapan informasi, 4) aspek kelayakan kegrafikan, yang mencakup: penggunaan font (jenis dan ukuran), lay out atau tata letak,

Pengembangan pembelajaran
PAI khususnya Akidah Akhlak se-
baiknya juga dikemas secara interaktif dan menarik. Salah satu caranya adalah dengan mengembangkan modul pembelajaran dengan mengintegrasikan berbagai macam pendekatan seperti salah satunya pendekatan Saintifik, dimana didalam kegiatannya terdapat 5 langkah kegiatan seperti mengamati, menanya, mengumpulkan informasi, mengasosiasi/menalar dan mengkomunikasikan yang menunjang keaktifan siswa dalam pembelajaran. Siswa memiliki kebebasan untuk belajar sesuai dengan keinginannya. Belajar menjadi tidak monoton, mengekang dan menegangkan (Abadi, 2015, p. 128)

Secara teknis modul Akidah Akhlak dengan pendekatan Saintifik memiliki tampilan yang menarik dengan jenis huruf Andalus dan ukuran huruf 12. Sedangkan untuk penulisan ayat Al-Quran dan Hadits jenis huruf Traditional Arabic, ukuran huruf 14. Disamping itu modul Akidah Akhlak juga dilengkapi dengan gambar-gambar dan haditshadits yang sesuai dengan teori, khususnya pada materi menghindari akhlak tercela (kikir dan serakah), yang dapat menunjang pemahaman 
siswa terhadap materi pembelajaran. Bahasa yang digunakan adalah bahasa Indonesia yang baik dan benar, menggunakan ejaan yang disempurnakan (EYD), bahasa sesuai dengan perkembangan kognitif siswa, struktur kalimat jelas dan sederhana, mudah dipahami, dan komunikatif.

Kevalidan modul Akidah Akhlak dengan pendekatan saintifik ini dapat dipertanggungjawabkan karena telah dinilai sangat valid oleh validator. Menurut van den Akker (1999) dalam Fatmawati, (2016, p. 95), perangkat pembelajaran dikatakan valid apabila ada keterkaitan yang konsisten dari setiap komponen perangkat pembelajaran yang dikembangkan dengan karakteristik model pembelajaran yang diterapkan. Berdasarkan pendapat di atas, maka dapat diketahui bahwasanya modul yang peneliti kembangkan sudah dikatakan sangat valid, karena modul tersebut memiliki komponen yang saling terkait, salah satunya yaitu kesesuaian dengan SK dan KD, kesesuaian dengan perkembangan siswa MIN, kesesuaian dengan kebutuhan bahan ajar, kebenaran substansi materi pembelajaran, memiliki manfaat untuk menambah wawasan siswa.

Sebagaimana dikatakan oleh Setiyadi (2017, p. 107), modul pembelajaran dapat dikatakan valid apabila semua validator menyatakan produk yang dikembangkan valid. Pendapat ini didukung oleh hasil penelitian Widiyanti (2014, p. 412) yang menyatakan bahwa sebuah modul dikatakan berkualitas dan layak digunakan apabila sudah terpenuhinya standar kevalidan yang dinilai oleh beberapa orang pakar dan ahli. Selain itu, Hala (2015, p. 93) juga menyatakan bahwa suatu produk dikatakan valid apabila instrumen yang dikembangkan telah didasari pada kajian rasional teoritik yang kuat serta memiliki konsistensi secara internal.

Hasil validasi dari beberapa orang validator mengenai kevalidan modul Akidah Akhlak dengan pendekatan saintifik, diperoleh rata-rata yaitu $89 \%$ dengan kategori sangat valid, dimana aspek yang dinilai yaitu sesuai dengan aspek-aspek penilaian modul yang berkualitas yang dikemukakan oleh Lidy dkk dalam Susilo, Siswandari \& Bandi, (2016, p. 51), di antaranya ialah: 1) aspek kelayakan isi, 2) aspek kelayakan bahasa, 3) aspek kelayakan penyajian, dan 4) aspek kelayakan kegrafikan.

\section{Praktikalitas Produk}

Praktikalitas modul ditentukan melalui hasil angket respon siswa, hasil angket guru dan hasil observasi. Tingkat kepraktisan dapat dilihat dari aspek apakah produk mudah digunakan oleh pendidik dan peserta 
didik. Hasil analisis angket respon siswa terhadap modul Akidah Akhlak dengan pendekatan Saintifik menunjukkan bahwa modul sangat praktis dengan nilai rata-rata $92 \%$. Hal ini menunjukkan bahwa modul Akidah Akhlak yang dikembangkan tersusun secara terkonsep dan dilengkapi dengan gambar-gambar dan pemberian warna yang menarik yang mampu meningkatkan prestasi belajar siswa. Siswa pun lebih mudah memahami materi dengan adanya contoh-contoh, hadits-hadits dan juga didukung dengan kegiatan saintifik di dalam modul Akidah Akhlak ini.

Sedangkan dari hasil angket guru, di dapatkan hasil rata-rata 97\% dengan kategori sangat praktis digunakan untuk siswa MI, khususnya pada siswa kelas V MIN 1 Tanah Datar. Modul yang peneliti kembangkan sangat membantu guru dalam menyampaikan materi secara mudah kepada siswa, yang dilengkapi dengan latihan-latihan ataupun tugas, sehingga pengetahuan siswa dapat diujicobakan secara langsung melalui pembelajaran dengan menggunakan modul, baik di sekolah maupun dirumah. Dengan menggunakan modul ini guru dapat menggunakan waktu pembelajaran lebih efektif.

Hasil dari penilaian kepraktisan modul melalui lembar observasi yang dilakukan oleh observer kepada guru
Akidah Akhlak yaitu diperoleh ratarata $86 \%$ dengan kategori sangat praktis. Guru dan siswa sangat antusias dalam melaksanakan pembelajaran dengan menggunakan modul yang diintegrasikan dengan pendekatan saintifik ini. Menurut Abduh, (2017, p. 309), Kegiatankegiatan pembelajaran saintifik dapat mengarahkan siswa untuk aktif berinteraksi serta dapat membangun pengetahuan mereka melalui kegiatan mengamati, menanya, mengumpulkan informasi dan mengkomunikasikan.

Secara umum penggunaan modul Akidah Akhlak dengan pendekatan Saintifik dalam pembelajaran Akidah Akhlak sangat membantu siswa belajar karena siswa bisa memahami lebih cepat materi ajar yang terdapat dalam modul sehingga penggunaan waktu lebih efektif. Modul Akidah Akhlak dengan pendekatan Saintifik membantu guru dalam menghadapi siswa dengan minat, kemampuan, dan tingkat kecerdasan yang berbeda-beda dalam belajar.

Terkait dengan aspek kepraktisan, hasil penelitian Nieveen (1999) dalam Haviz (2013, p. 34), memperlihatkan cara mengukur tingkat kepraktisan. Hasil penelitian ini menjelaskan bahwa tingkat kepraktisan dilihat dari penjelasan apakah guru 
dan pakar lain memberikan pertimbangan bahwa materi mudah dan dapat digunakan oleh guru dan siswa, Nieveen juga menjelaskan produk hasil pengembangan, disimpulkan praktis jika (1) praktisi menyatakan secara teoritis produk dapat diterapkan di lapangan dan (2) tingkat keterlaksanaan produk termasuk kategori baik.

Selain itu, menurut Akker (1999) dalam Fatmawati, (2016, p. 95), perangkat pembelajaran yang dikembangkan (yang dimaksud dengan perangkat pembelajaran yaitu bahan ajar), dimana bahan ajar tersebut menurut (Amri, 2013, p. 98-104) salah satunya berupa modul. Pengembangan modul dikatakan berkualitas jika memenuhi tiga kriteria, yaitu validitas, kepraktisan, dan efektivitas. Perangkat pembelajaran dikatakan praktis apabila perangkat tersebut mudah dan dapat dilaksanakan.

Berdasarkan pendapat di atas, maka dapat diketahui bahwasanya modul yang peneliti kembangkan dapat digunakan, karena telah memenuhi indikator praktis, dimana modul yang peneliti kembangkan terkategori mudah dipahami dan dapat dilaksanakan dengan baik oleh guru dan siswa. Selain itu, menurut Suryani, Surya \& Mukhtar (2016, p. 34), produk pembelajaran dikatakan praktis apabila lembar angket respon siswa mencapai kategori praktis.
Kepraktisan dari angket respon siswa terkait dengan ketertarikannya dengaan produk yang dikembangkan. Angket respon tersebut diberikan pada akhir proses pembelajaran. Susanti (2017, p. 166) juga berpendapat bahwa modul dikatakan praktis apabila modul tersebut dapat membantu guru dalam proses pembelajaran dan bagi siswa dapat mempermudah dalam pemahaman materi yang dikembangkan.

Pendapat di atas juga dipertegas oleh pendapat Setiyadi (2017, p. 106), yang menyatakan bahwa modul dikatakan praktis dapat dinilai dari beberapa hal, diantaranya ialah (1) keterlaksanaan pembelajaran, serta (2) respon siswa dan guru. Hasil dari keterlaksanaaan pembelajaran menggunakan modul Akidah Akhlak dengan pendekatan saintifik diperoleh rata-rata $86 \%$ dengan kategori sangat praktis. Hal ini berarti modul tersebut sudah layak digunakan oleh guru dan siswa di sekolah. Sedangkan hasil dari angket respon siswa diperoleh rata-rata $93 \%$ dengan kategori sangat praktis, dan hasil dari angket respon guru ialah diperoleh rata-rata 97\% dengan kategori sangat praktis. Jadi, berdasarkan perolehan tersebut, dapat diambil kesimpulan bahwasanya modul yang peneliti kembangkan mudah dipahami dan dilaksanakan oleh guru dan siswa di 
dalam proses pembelajaran di sekolah.

\section{KESIMPULAN}

Hasil pengembangan Modul Akidah Akhlak dengan pendekatan Saintifik, terkategori sangat valid, setelah dinilai oleh validator dengan nilai rata-rata $89 \%$. Maksud dari sangat valid yaitu sudah teruji kebenarannya. Sedangkan hasil pengembangan Modul Akidah Akhlak dengan pendekatan Saintifik dinyatakan sangat praktis dengan nilai rata-rata $92 \%$, yaitu mudah digunakan dan dapat dipahami oleh guru dan siswa.

\section{Saran}

1. Guru mata pelajaran Akidah Akhlak dan siswa MIN 1 Tnaah Datar sebaiknya menggunakan modul Akidah Akhlak ini di dalam proses belajar mengajar, dan tidak hanya digunakan ketika mengerjakan latihan atau tugas saja.

2. Modul Akidah Akhlak ini sebaiknya dapat dijadikan rujukan oleh tenaga pendidik untuk mengembangkan materi dan mata pelajaran lainnya di MIN 1 Tanah Datar.

3. Kepala MIN 1 Tanah Datar sebaiknya dapat memberikan rekomendasi kepada tenaga

\section{KEPUSTAKAAN ACUAN}

Abadi, G. F. (2015). Inovasi Pembelajaran Pendidikan Agama Islam Berbasis ELearning. Jurnal Tasyri'. 22(2): 127-138

Abduh, M. (2017). Interaksi Pada Pendekatan Saintifik (Kajian Teori Scaffolding). Seminar Nasional Pendidikan PGSD UMS $\mathcal{E}$ HDPGSDI Wilayah Jawa, 2(9), 307-318.

Amri, S. (2013). Pengembangan dan Model Pembelajaran dalam Kurikulum 2013. Jakarta: PT Prestasi Pustakaraya.

Erny, E., Haji, S., \& Widada, W. (2017). Pengaruh Pendekatan Saintifik pada Pembelajaran Matematika Terhadap Kemampuan Pemecahan Masalah dan Kemampuan Berpikir Tingkat Tinggi Siswa Kelas X IPA SMA Negeri 1 Kepahiang. Jurnal Pendidikan Matematika Raflesia, 2(1).

Fatmawati, A. (2016). Pengembangan Perangkat Pembelajaran Konsep Pencemaran Lingkungan Menggunakan Model

Pembelajaran Berdasarkan 
Masalah untuk SMA Kelas X: Jurnal EduSains, 4(2)

Hala, Y. (2015). Pengembangan Perangkat Pembelajaran Biologi Berbasis Pendekatan Saintifik Pada Konsep Ekosistem Bagi Siswa Sekolah Menengah Pertama. Journal of Educational Science and Technology (EST), 1(3).

Haviz, M. (2013). Research and Development Penelitian di Bidang Kependidikan yang Inovatif Produktif dan Bermakna. Jurnal Ilmu Pendidikan. 16(1): 28-43.

Riduwan. (2005). Belajar Mudah Penelitian untuk Guru-Kariawan dan Peneliti Pemula. Bandung: Alfabeta.

Rusli, N., Sulaeman, Yusuf, M.Y., Nata, A., Aminuddin. (1992). Materi Pokok Akidah Akhlak I. Jakarta: Ditjen Pembinaan Kelembagaan Agama Islam, Departemen Agama, Universitas Terbuka.

Sani, A. R. (2014). Inovasi Pembelajaran. Ed. 1, Cet. 2. Jakarta: Bumi Aksara.

Setyosari, P. (2010). Metode Penelitian Pendidikan dan Pengembangan. Ed.

1, Cet. 1. Jakarta: Kencana.

Sugiyono. (2017). Metode Penelitian dan
Pengembangan (Research and Development). untuk Bidang: Pendidikan, Manajemen, Sosial, Teknik. Cet. 3. Bandung: Alfabeta.

Suhartati. (2016). Penerapan Pendekatan Saintifik pada Materi Relasi dan Fungsi di Kelas X MAN Banda Aceh. Jurnal Peluang. 4(2), 56-65.

Suryani, D. R. Surya, E. \& Mukhtar, (2016). Pengembangan Modul Matematika Berbasis Pendekatan Pembelajaran Saintifik di SMP Negeri 8 Padangsidempuan. Jurnal Paradikma, 9(3), 28-35.

Susanti, R. (2017). Pengembangan Modul Pembelajaran Pai Berbasis Kurikulum 2013 di Kelas V SD Negeri 21 Batubasa, Tanah Datar. JMKSP (Jurnal Manajemen, Kepemimpinan, dan Supervisi Pendidikan), 2(2).

Susilo, A. Siswandari \& Bandi. (2016). Pengembangan Modul Berbasis Pembelajaran Saintifik untuk Peningkatan Kemampuan Mencipta Siswa dalam Proses Pembelajaran Akuntansi Siswa Kelas XII SMA N I Slogohimo 2014. Jurnal Pendidikan Ilmu Sosial, 26(1), 50-56.

Setiyadi, M. W. (2017). Pengembangan modul pembelajaran biologi berbasis pendekatan saintifik 
untuk meningkatkan hasil Keanekaragaman Hayati belajar siswa. Journal of Berbasis Pendekatan Saintifik Educational Science and Technology untuk Siswa Kelas X SMA. (EST), 3(2), 102-112. BioEdu, 3(3).

Widiyanti Sawitri, D. I. T. A. (2014).

Pengembangan Modul 